\title{
Survey of Fungal Diseases of Some Vegetables and Fruits in Aswan, EGYPT
}

\author{
Mohamed S Massoud \\ Botany Dept., Faculty of Science, Aswan University, Aswan, 81528, EGYPT
}

\begin{abstract}
Fifteen species belonging to 9 terrestrial fungal genera were isolated from diseased fruits and vegetables on PDA media during this investigation. Aspergillus came in high incidence genera and represented by three species namely; A. flavus var colamnaris, A. niger and A. ochraceus. Another four fungal genera were came in the second position after Aspergillus and represented by two identified species these were; Acremonium, Alternaria, Fusarium and Penicillium. The remaining four fungal genera which isolated were representative by only one species were; Botryotrichum sp., Gilmaniela humicola, Mucor hiemalis and Torula $s p$. Solanum lycopersicum was yielded the highest number of genera and species ( 7 and 11, respectively). Psidium guava was yield the lowest number of fungal genera and species (1 and 1). All fungal which isolated in this investigation were screened for their ability to cellulose production on CMC agar plates within 3 days, among all tested isolates Aspergillus flavus and Fusarium proliferatum were the highest fungal isolates produced clear zone $(3.65 \mathrm{~mm})$ and $(3.15 \mathrm{~mm})$ respectively.
\end{abstract}

Key Words: Aspergillus, Fruit, Psidium guava, Solanum lycopersicum, Vegetables

\section{Intriduction}

Fungi are universally present in all types of natural habitats and from one of the most important component of an ecosystem as decomposers. It has been known that vegetables and fruits plays a vital role in human nutrition by supplying the necessary growth factors such as vitamins and essential minerals in human daily diet and that can help to keep a good and normal health. Vegetables and fruits are widely distributed in nature, one of the limiting factors that influence the vegetables and fruits economic value is the relatively short shelf-life period by pathogens attacked. It is estimated that about $20-25 \%$ of the harvested vegetables and fruits are decayed by pathogens during post - harvest handling even in developed countries [1-2]. Fungal vegetables and fruits infection may occur during the growing season, harvesting, handling, transport, post - harvest storage, marketing conditions and after purchasing by the consumer. Vegetables and fruits containing high levels of nutrient elements and sugars and their low $\mathrm{pH}$ values make them particularly desirable to fungal decaying [3].

Cellulose is commonly degraded by an enzyme called cellulase. This enzyme is produced by several microorganisms, mainly by bacteria and fungi. Although a large numbers of microorganisms are capable of degrading cellulose, only few of these produce significant quantities of cell free enzymes capable of completely hydrolyzing crystalline cellulose in vitro. Fungi are the main cellulose producing microorganisms, although a few bacteria and actinomycetes have also been reported to yield cellulose activity [4].

Several works have been dealt with fungi which recovered from many vegetable and fruits from different parts of the world [5-6-7-8-9-10-11 - 12]. The production of cellulases by fungi was studied by many investigators such as [13-14-15].

The Aim of this investigation were represents an extension of a series of investigations in Upper Egypt, it is represents a survey of the terrestrial fungi from diseased fruit and vegetables which were collected from different markets in Aswan area and screening of some fungi for cellulose activity.

\section{Materials and Methods}

\section{Collection and Isolation of fungi from fruits and vegetables}

The infected nine fruits viz. Allium cepa, Solanum lycopersicum, Solanum tuberosum, Citrus aurantifolia, Cucurnis sativus, Cucurbite pepo, Fragraria grandiflora, Psidium guava and Citrus reticulata were collected from markets in Aswan city. Samples were put in separate sterilized plastic bags and transferred to the laboratory. The infected tissues transferred individually to Petri dishes containing $20 \mathrm{ml}$ of PDA medium. Incubate the dishes at $30^{\circ} \mathrm{C}$ for 5 days then dishes were examined and identified.

\section{Pathogenicity test}

Some of isolated fungi were used to confirm their pathogenicity in their respective hosts. Some fresh healthy samples were brought in to the laboratory and surface sterilized with $0.1 \% \mathrm{Hgcl} 2$. For inoculations, cork borers of $(2 \mathrm{~mm})$ diameter were sterilized for used. The inoculated samples and their respective controls were kept under sterile conditions at room temperature under bell jars. The artificially inoculated samples were 
examined daily \& the extent of damage was recorded. The pathogens were re-isolated and disease symptoms were clearly evident, the culture and symptoms signs were compared with original.

\section{Screening of cellulolytic fungi.}

The isolated fungal cultures were screened for their ability to produce cellulases complex following the method of [16]. Czapek-Dox medium used in this method contained (g/l); sucrose - 30, NaNO3 - 2, K2HPO4 $1, \mathrm{MgSO} 4-0.05, \mathrm{Kcl}-0.5$, FeSO4 - 0.01, carboxy- methyl cellulose - 1\%, Agar agar - 20. $\mathrm{pH}$ of the medium was adjusted to 5. After autoclaving the medium was poured into Petri plates and allowed to solidify. Cavities of $6 \mathrm{~mm}$ size were made in the solidified medium and inoculated with $0.1 \mathrm{ml}$ of spore suspension prepared from 7 day old slants. The plates were incubated at room temperature $\left(28 \pm 2{ }^{\circ} \mathrm{C}\right)$ for three days to allow fungal growth, then again incubated for $18 \mathrm{~h}$ at $50{ }^{\circ} \mathrm{C}$ which is the optimum temperature for cellulases activity. After incubation, $10 \mathrm{ml}$ of $1 \%$ Congo - Red staining solution was added to the plates that were shaken $15 \mathrm{~min}$. The Congo - Red staining solution was then discarded, $10 \mathrm{ml}$ of $1 \mathrm{~N} \mathrm{NaOH}$ was added to the plates and shaken again for 15 minutes. Finally $1 \mathrm{~N} \mathrm{NaOH}$ was also discarded and the staining of the plates was analyzed by noticing the formation of yellow zones around the fungal spore inoculated wells.

\section{Identification of the Fungal genera and species}

The following references were used for the identification of the recovered fungi [17 $-18-19-20-21$ $-22-23-24-25-26-27-28-29-30-31]$.

\section{Results And Discussion}

Fifteen species belonging to 9 terrestrial fungal genera were isolated from diseased fruits and vegetables on PDA media during this investigation (Table, 1).

Aspergillus came in the first position with high incidence as highest fungal genera and represented by three species namely; A. flavus var colamnaris, A. niger and A. ochraceus. The genus Aspergillus was recovered from Allium cepa, Solanum lycopersicum, S. tuberosum, Citrus lemon, Cucurnis sativus and Cucrbite pepo. A. flavus var colamnaris was isolated from 5 fruits and vegetables, whereas A. niger was recovered from Solanum lycopersicum only. Aspergillus ochraceus was isolated from Solanum lycopersicum and Cucurnis sativus only.

Four fungal genera were came in the second position after Aspergillus and represented by two identified species these were; Acremonium, Alternaria, Fusarium and Penicillium. Acremonium, which represented by A. butyri and A. strichtum, were recovered from Solanum lycopersicum and Solanum tuberosum only, while not recovered from the remaining investigated plants. Alternaria were isolated from Solanum lycopersicum, Citrus aurantifolia, Cucurnis sativus, Cucurbit pepo, Fragaria grandiflora while absent in the other tested plants, this genus was represented by A. alternate and A. brassicicola. Fusarium was recovered from Allium cepa, Solanum lycopersicum and Solanum tuberosum only, Fusarium was represented by two identified species were; $F$. moniliforme and $F$. proliferatum. Penicillium ( $P$. janthinellum and P. italicum) was isolated from Solanum lycopersicum, Psidium guava and Citrus reticulate.

The remaining four fungal genera which isolated were representative by only one species were; Botryotrichum sp., Gilmaniela humicola, Mucor hiemalis and Torula sp. These genera were isolated from 3 to one investigated plants.

Similar results on post - harvest fungi on storage fruits and vegetables were reported by many investigators as [32-33-34-35-36-37-38].

Table (1): Fungal genera and species which were recovered from different fruits and vegetables samples collected from different markets in Aswan.

\begin{tabular}{|l|l|l|l|l|l|l|l|l|l|l|}
\hline \multirow{2}{*}{ Fungal genera and species } & \multicolumn{7}{|c|}{ fruits and vegetables samples } \\
\cline { 2 - 11 } & 1 & 2 & 3 & 4 & 5 & 6 & 7 & 8 & 9 \\
\hline Acremonium: & - & + & + & - & - & - & - & - & - \\
\hline A. Butyri & - & + & + & - & - & - & - & - & - \\
\hline A. Strichtum & - & + & - & - & - & - & - & - & - \\
\hline Alternaria: & - & + & - & + & + & + & + & - & - \\
\hline A. Alternate & - & + & - & + & + & + & + & - & - \\
\hline A. Brassicicola & - & - & - & - & + & + & - & - & - \\
\hline Aspergillus: & + & + & + & + & + & + & - & - & - \\
\hline A. flavus var colamnaris & + & + & + & + & - & + & - & - & - \\
\hline A. niger & - & + & - & - & - & - & - & - & - \\
\hline A. ochraceus & - & + & - & - & + & - & - & - & - \\
\hline Botryotrichum sp. & - & + & + & - & - & - & + & - & - \\
\hline Fusarium: & + & + & + & - & - & - & - & - & - \\
\hline F. moniliforme & + & + & + & - & - & - & - & - & - \\
\hline F. proliferatum & - & + & + & - & - & - & - & - & - \\
\hline
\end{tabular}




\begin{tabular}{|l|l|l|l|l|l|l|l|l|l|}
\hline Gilmaniela humicola & - & - & - & + & - & - & - & - & + \\
\hline Mucor hiemalis & - & - & + & - & - & - & - & - & - \\
\hline Penicillium : & - & + & - & - & - & - & - & + & + \\
\hline P. janthinellum & - & + & - & - & - & - & - & - & - \\
\hline P. italicum & - & - & - & - & - & - & - & + & + \\
\hline Torula sp. & - & + & - & - & - & - & - & - & - \\
\hline
\end{tabular}

1- Allium cepa

4- Citrus aurantifolia

7- Fragaria grandiflora
2- Solanum lycopersicum

5- Cucurnis sativus

8- Psidium guava
3- Solanum tuberosum

6- Cucurbit pepo

9- Citrus reticulate

Regarding to terrestrial fungal genera and species which recovered during this investigation (Fig. 1) showed that: Solanum lycopersicum was yielded the highest number of genera and species ( 7 and 11, respectively). Psidium guava was yield the lowest number of fungal genera and species (1 and 1). The remaining seven investigated fruits and vegetables were yield moderate numbers fungal genera and species during this investigation and ranging from ( $2-3$ genera) and ( $2-4$ species).

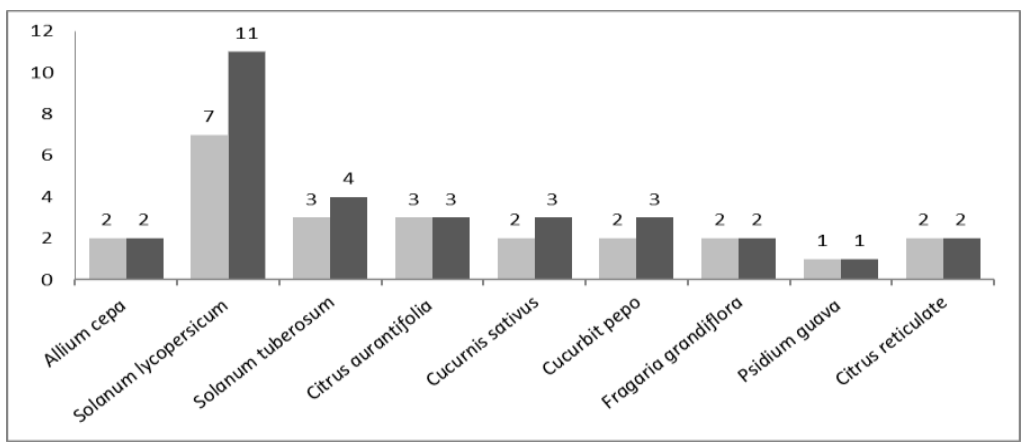

Fig (1): Numbers of fungal genera and species which were recovered from fruits and vegetables

Results in table (2) indicated that, all tested isolates were able to synthesize extracellular cellulose but in different levels. Aspergillus flavus and Fusarium proliferum were the highest investigated fungi produce clear zone of hydrolysis in CMC agar plates within 3 days. Aspergillus flavus was $(3.65 \mathrm{~mm})$ followed by Fusarium proliferum (3.15 mm); Acremonium strictum (1.9 mm); Penicillium janthilinum (1.65 mm); Aspergillus ochraceus (1.5 mm); Alternaria alternata $(1.15 \mathrm{~mm})$; Fusarium moniliforme $(1.05 \mathrm{~mm})$; Botryotrichum sp. $(0.9$ $\mathrm{mm})$; Acremonium butyri $(0.85 \mathrm{~mm})$; Torula sp. $(0.5 \mathrm{~mm})$ and Mucor hiemalis $(0.4 \mathrm{~mm})$. Most of tested species for extracellular cellulose were previously examined in different part around the world by [39-40-41-4243] when they isolated, screening, production and purification of cellulase by fungi.

Table (2): Biometric features of cellulolytic fungal cultures..

\begin{tabular}{|l|c|}
\hline \multicolumn{1}{|c|}{ Tested fungal genera \& species } & Zone of hydrolysis on CMC agar plates (cm) \\
\hline Penicillium janthilinum & 1.65 \\
\hline Alternaria alternata & 1.15 \\
\hline Acremonium butyri & 0.85 \\
\hline Fusarium proliferum & 3.15 \\
\hline Aspergillus ochraceus & 1.5 \\
\hline Acremonium strictum & 1.9 \\
\hline Botryotrichum sp. & 0.9 \\
\hline Fusarium moniliforme & 1.05 \\
\hline Aspergillus flavus & 3.65 \\
\hline Mucor hiemalis & 0.4 \\
\hline Torula species & 0.5 \\
\hline
\end{tabular}

\section{References}

[1] Droby S., Improving quality and safety of fresh fruits andvegetables after harvest by the use of biocontrol agents and natural materials. Acta Horticul. 709, 2006, 45-51.

[2] Zhu SJ., Non-chemical approaches to decay control in postharvest fruit. In: Noureddine, B., Norio, S. (Eds.), Advances in Postharvest Technologies for Horticultural Crops. Research Signpost, Trivandrum, India, 2006, pp. 297-313.

[3] Singh D, Sharma RR., Postharvest diseases of fruit and vegetables and their management. In: Prasad, D. (Ed.), Sustainable Pest Management. Daya Publishing House, New Delhi, India, 2007. 
[4] M. Jayant, J. Rashmi, M. Shailendra and Y. Deepesh, Production of cellulase by different co-culture of Aspergillus niger and Penicillium chrysogenum from waste paper, cotton waste and baggase. Journal of Yeast and Fungal Research Vol. 2(2), 2011, pp. 24-27.

[5] Yulia, E. and Shipton, W. A., Fungal leaf mycoflora of selected aromatic plants in north Queensland. Australasian mycologist, 27 (1), 2008, $7-12$.

[6] Rolf, I. P., Roar, M., Hans, R. G., Growth of pot Roses and post-harvest rate of water loss as affected by air humidity and temperature variations during growth under continuous light. Scientia Horticulturae 114, 2007, 207-213

[7] Christophe, A., Philippe, B., Guillaume, C. and Virginie, H., Changes in physicochemical characteristics and volatile compounds of apricot (prunus armeniaca L. CV. Bergeron) during storage and post-harvest maturation. J. Food Chemistry, 119, 2010, 1386-1398

[8] Baiyewu, R. A., Amusa, N. A., Ayoola, O.A., and Babalola, O.O., Survey of the post-harvest diseases and aflatoxin contamination of marketed pawpaw fruit (Carica papayal) in south western Nigeria. African journal of agricultural research Vol. 2(4), 2007, 178-181.

[9] Enefe, P., Ndidi, and A., Akeem, Antioxidant enzyme activity during post-harvest deterioration of cassava (Manihot esculenta) root tubers. International journal of agriculture \& biology. 13, 2011, 455-457.

[10] Ibiam, O.F.A., and Egwu, B.N, Post-harvest seed-borne diseases associated with the seeds of three varieties of groundnuts, (Arachis hypogaea L) Nwakara, Kaki, and campalla. Agriculture and Biology Journal of North America., 2(4), 2011, 598.602

[11] Rashed, R., Al-Hindi, Ahmed, R., Al-Najada, and Saleh, A., Mohamed, Isolation and identification of some fruit spoilage Fungi: Screening of plant cell wall degrading enzymes. African Journal of Microbiology Research Vol. 5(4), 2011, $443-448$.

[12] Nirupama, P., Neeta, B. G., and T.V. Ramana, R., Effect of post - Harvest treatments on physicochemical characteristics and shelf life of tomato (lycopersicon esculentum mill.) Fruits during storage. American-Eurasian J. Agric. \& Environ. Sci., 9(5), 2009, 470479.

[13] Abolfazl, L., Mohammed, A. T. G., Gholam, A. R., and Ahmad, A., Screening of some zygomycetes for cellulase activity. African Journal of Biotechnology. Vol. 9 (27), 2010, $4211-4216$.

[14] Luis, H. S. G., Simone, C. P. N., Michele, M., Ana Carolina, S. R., Valéria, C. S., Fabiana, F. Z., Ana Carla, M. M. A., Altino, B. J., and Maria de Lourdes, T. M. P., Screening of filamentous fungi for production of enzymes of Biotechnological interest. Brazilian Journal of Microbiology 37, 2006, 474 - 480.

[15] Sadaf, J., Nazia Khan, Samsan, J., Muhammad, S., Saleem, S., Aqeel, A. and Shakeel, A. K., Screening and characterization of fungal cellulase isolated from the native environmental source. Pak. J. Bot., 37 (3), 2005, 739 - 748.

[16] Teather, R.M., Wood, P.J., Use of Congo red Polysaccharide interactions in enumeration and characterization of cellulolytic bacteria from the bovine rumen. Applied and Environmental Microbiology 43, 1982, 777-780.

[17] Brown, A. H. S., and Smith, G., The genus Paecilomyces Bainier and its perfect stage Byssochlamys Westling. Trans. Br. Mycol. Soc. 40, 1957, 17- 89 .

[18] Morton, F. J., and Smith, G., The genus Scopulariopsis Bainier, Microascus Zukal and Doratomyces corda. Mycological papers, No. 86, 1963 Commonwealth Mycological Institute, Kew, England.

[19] Fassatiova, O., Notes on genus Humicola Traaen. I. Ceska Mycologie 18, 1964, 102-108.

[20] Raper, K. B., and Fennell, D. J., The genus Aspergillus. P. 686, 1965, Williams and Wilkins, Baltimore, U.S.A.

[21] Simmons, E. G., Typification of Alternaria, Stemphylium and Ulocladium, Mycologia 59, 1967, 67.

[22] Barron, G. L., The genera of Hyphomycetes from soil. P. 363, 1968, Williams \& Wilkins Co., Ballimore

[23] Ames, L. A., A monograph of the Cheatomiaceae. P. 65, 1969, Wheldon \& Wesleg L.T.D. New York.

[24] Ellis, M. B., Dematiaceous Hyphomycetes. P. 608, 1971, Common. Mycol. Ins., Kew, Surrey, England.

[25] Ellis, M.B., More Dematiaceous Hyphomycetes. P.507, 1976, Commowelth, Mycological Institute, Kew, Surrey, England.

[26] Booth, C., "The genus Fusarium" Commonw. Mycol. Ins., 1971, Kew, Surry, England.

[27] Booth, C., Fusarium Laboratory guide to the identification of the major species. Commonw. Mycol. Inst., 1977, Kew, Surrey, England.

[28] Domsch, K. H. and Gams, W., "Fungi in agriculture soils". P. 290, 1972, published by Longman.

[29] Samson, R. A., Paecilomyces and some allied Hyphomycetes. Studies in Mycology. No.6., 1974, Contraalbureau voor Schimmelcultures, Baarn, Netherlands.

[30] Pitt, J. I., The genus Penicillium and its teleomorphic states Eupenicillium and Talaromyces. P. 634, 1979, Acad. Press. London, New York.

[31] Domsch, K. H., Gams, W., and Andersone, T. H., "Compendium of Soil fungi”. P. 859, 1980, Acad. Press, London.

[32] Philip Susamma., Fruits crops diseases in the field of storage. Kalyani publishers, 2002, New Delhi.

[33] Sharma, N, and Alam, M, Mashkoor., Post-harvest diseases of horticulture perishables, 1998. International Book Distributing Co luckhnow.

[34] Basha, RA, Lal, AA, Gupta, S, Srivastava, R, and Gupta, P., Eco friendly management of post-harvest fungal pathogen causing crown rot and anthracnose of banana (Musa paradisica) in Allahabad.J Mycol pl pathol. 39(1), 2009, 14-18.

[35] Cherian, TT., Post-harvest fungal diseases of some fruits of kerala. B.F.Rodrigues,H.N.Gour,D.J.Bhat \& N.kamat eds. Advances in fungal diversity and hast pathogen interactions.Goa university,Goa. 2005, PP-26-36.

[36] Ghurde, MU, and pachkhede, AU., The market and storage diseases of fruits from Amravati (Maharashtra) india. Bionanofrontier. 3(2), 2010, 325-327.

[37] Gadgile, DP, and Chavan, AM., Post-harvest fungal diseases of mango fruits. (Proceedings of National Conference "Role of Non Agricultural Institutional in the improvement of Agricultural Technology" on Jan 22-23,2011 at Gunjoti) Bionanofrontier. Special issue, 2011, 44-47 pp.

[38] Bhale, U N., Survey of market storage diseases of some important fruits of Osmannabad District [M. S.] India. Science Research Reporter 1(2), 2011, 88-91.

[39] M., Charitha Devi, and M., Sunil Kumar, Production, Optimization and Partial purification of Cellulase by Aspergillus niger fermented with paper and timber sawmill industrial wastes. J. Microbiol. Biotech. Res., 2 (1), 2012, 120 - 128.

[40] G., Ramanathan, S., Banupriya, and D., Abirami, Production and optimization of cellulase from Fusarium oxysporum by submerged fermentation. J. Scientific \& industrial Research. Vol. 69, 2010, 454-459.

[41] Gisele Eleonora Kikot, Roque Alberto Hours, and Teresa Maria Alconada, Extracellular Enzymes of Fusarium graminearum Isolates. Braz. Arch. Biol. Technol. Vol. 53 (4), 2010, $779-783$.

[42] A., Lotfi, M., A., Tajick Ghanbary, G., Ranjbar, and A., Asgharzadeh, Screening of some soil Fusaria for cellulose activity and partial purification of cellulose. J. Biodiversity and Ecological Science, 1 (2), 2011, 123 - 132.

[43] B., Lalitha Kumari, M., Hanuma, and P., Sudhakar, Isolation of Cellulase Producing Fungi from Soil, Optimization and Molecular Characterization of the Isolate from Maximizing the Enzyme Yield. World Journal of Science and Technology, 1 (5), 2011,1 - 9 